\title{
Suppression of PMN-chemotaxis by different molecular weight fractions of equine seminal plasma
}

\author{
M.H.T. Troedsson', R.K. Franklin² and B.G. Crabo² \\ Department of Clinical and Population Sciences, College of Veterinary Medicine ${ }^{1}$, and Animal Sciences², University of Minnesota, St. Paul, USA
}

\begin{abstract}
Summary
The objective of this study was to determine the molecular weight of the factors in equine seminal plasma that suppress chemotaxis of polymorphonuclear neutrophils (PMNs). Blood plasma was pooled from four healthy horses and seminal plasma was pooled from two fertile stallions. Both the blood plasma and the seminal plasma were stored at $-20^{\circ} \mathrm{C}$ until used. Complement in blood plasma was activated with $\mathrm{E}$. Coli lipopolysaccharide (LPS) in the presence of $2 \%, 10 \%, 20 \%$, and $30 \%$ seminal plasma. In addition, blood plasma and heat inactivated blood plasma without seminal plasma were used as controls. An aliquot chosen to standardize the amount of blood plasma was diluted with McCoy's medium into a chemotactic chamber. Chemotaxis of blood-derived equine PMNs toward the chemoattractants was determined after incubation at $37^{\circ} \mathrm{C}$ for 45 minutes. Results were expressed as the percentages of positive controls (LPS-activated blood plasma in the absence of seminal plasma), and the mean of each level of seminal plasma was compared using the Statistical Analysis System, general linear model, and Duncan's multiple range test. Significance was set at $P<0.05$. Seminal plasma inhibited PMN-chemotaxis in a dose dependent manner $(P<0.05)$. PMN-chemotaxis was more suppressed by seminal plasma than by heat inactivated blood plasma $(P<0.05)$. In a second experiment, seminal plasma proteins were separated in three different molecular weight fractions $(<10,000,<50,000$, and $<100,000 \mathrm{MW}$ ) by the use of Centricon ultracentrifugation (Amicon Inc.). Complement in blood plasma was activated with E. Coli LPS in the presence of $10 \%$ seminal plasma fractions with a molecular cut off of 10,000,50,000, and 100,000 MW. All seminal plasma fractions suppressed PMN-chemotaxis $(P<0.05)$. The most marked chemotaxis suppression was found in the 50,000-100,000 MW fraction. Although heat inactivation of blood plasma caused a suppression of chemotaxis, this suppression was less than that caused by all seminal plasma fractions $(P<0.05)$. It was concluded that more than one macromolecule in seminal plasma suppresses $P M N$-chemotaxis. Although inactivation of complement is involved in this mechanism, additional factors may contribute to the observed suppression.
\end{abstract}

Keywords: $\quad$ Equine, seminal plasma, PMN-chemotaxis

\section{Suppression der Chemotaxis neutrophiler Granulozyten durch Seminalplasmafraktionen verschiedenen Molekulargewichtes}

Die Zielsetzung dieser Studie war es, diejenigen Faktoren des equinen Seminalplasmas, die die Chemotaxis polymorphnukleärer Leukozyten (PMN) unterdrücken, in Bezug auf ihr Molekulargewicht (MG) zu ermitteln.

Blutplasma von vier gesunden Pferden sowie Seminalplasma von zwei fertilen Hengsten wurden gewonnen und bis zum Gebrauch bei $-20^{\circ} \mathrm{C}$ gelagert. Komplement im Blutplasma wurde durch E. coli Lipopolysaccharide (LPS) in Seminalplasma (2\%, 10\%, 20\%, 30\%) aktiviert. Zudem wurden Blutplasma sowie hitzeinaktiviertes Blutplasma ohne Zusatz von Seminalplasma als Kontrollansätze verwendet. Ein zur Standardisierung der Blutplasmamenge geeignetes Aliquot wurde in Mc Coy's Medium verdünnt und in eine Chemotaxis-Kammer verbracht. Die Chemotaxis der aus dem Blut stammenden equinen PMNs gegenüber den Chemoattraktantien wurde nach 45minütiger Inkubation bei $37^{\circ} \mathrm{C}$ bestimmt. Die Ergebnisse wurden als Prozentsatz gegenüber den positiven Kontrollen (LPS-aktiviertes Blutplasma ohne Zusatz von Seminalplasma) ausgedrückt. Chemotaxis wurde dabei mittels des statistischen Analysensystems, des generellen linearen Modells und Duncan's multiple range Tests mit den positiven Kontrollen verglichen. Die Signifikanz wurde bei $\mathrm{P}<0.05$ festgesetzt.

Für Seminalplasma konnte eine dosisabhängige Inhibition der PMN-Chemotaxis $(P<0.05)$ gezeigt werden. Diese war im Vergleich mit hitzeinaktiviertem Blutplasma signifikant größer $(P<0.05)$.

In einem zweiten Experiment wurden die Proteine des equinen Seminalplasmas mittels Centricon Ultrazentrifugation (Amicon Inc.) bezüglich dreier unterschiedlicher Molekulargewichte fraktioniert ( $M G<1.000,<50.000$, und <100.000). Das Komplement des Blutplasmas wurde jeweils in Anwesenheit von 10\% der drei unterschiedlichen Seminalplasmafraktionen durch E. coli LPS aktiviert. Für alle drei Fraktionen konnte eine signifikante $(P<0.05)$ Suppression der PMN-Chemotaxis gezeigt werden. Diese war in der Fraktion 50.000-100.000 MG am deutlichsten ausgeprägt. Auch eine Hitzeinaktivierung des Blutplasmas verursachte eine Unterdrückung der Chemotaxis, welche allerdings weniger deutlich war als diejenige jeder einzelnen Seminalplasmafraktion $(P<0.05)$.

Aus den Versuchsreihen wurde geschlossen, daß mehr als eine Molekulargewichtsfraktion des equinen Seminalplasmas einen suppressiven Effekt auf die PMN-Chemotaxis hat. Neben einer möglichen Komplementinaktivierung, scheinen für diesen Mechanismus noch weitere Faktoren verantwortlich zu sein.

Schlüsselwörter: Pferd, Seminalplasma, PMN-Chemotaxis

\section{Introduction}

Breeding-induced endometritis is a normal physiological response to intrauterine deposition of semen in the mare and serves to clear the uterus from excess semen and bacterial contamination at the time of breeding (Kotilainen et al.,
1994; Troedsson, 1995). In order not to be detrimental to the embryo, it is important that inflammation subsides well before the embryo descends into the uterine lumen at 5-6 days after fertilization (Betteridge et al., 1982; Freeman et al., 
1992). We have recently demonstrated that semen plays an active role in the regulation of post-breeding inflammation in mares (Troedsson, 1995; Troedsson et al., 1995 a,b; Troedsson et al., 1998a). Spermatozoa are capable of initiating chemotaxis of polymorphonuclear neutrophils (PM$\mathrm{Ns}$ ) from the blood circulation into the uterine lumen by activation of complement (Troedsson et al., 1995a). In contrast to spermatozoa, seminal plasma appears to inhibit complement activation, suppress PMN-chemotaxis, and suppress PMN-phagocytosis of spermatozoa (Troedsson et al., 1998a). Thus, the mechanism of post-breeding inflammation seems to be both up- and down-regulated by seminal components, and seminal plasma appears to be an important modulator of post-breeding inflammation. We hypothesize that the suppressive effect of seminal plasma on complement dependent PMN-chemotaxis is caused by a specific protein in seminal plasma. The objective of this study was to determine the molecular weight range of the seminal plasma factor that suppresses PMN-chemotaxis.

\section{Materials and methods}

\section{Preparation of seminal plasma}

Semen was collected with the use of a Missouri model artificial vagina from two stallions with known fertility. Immediately following collection, the semen was transported to the laboratory for preparation of seminal plasma. The ejaculate was centrifuged at $400 \times \mathrm{g}$ for 10 minutes, and the seminal plasma was removed and centrifuged twice at $3000 \times \mathrm{g}$ in order to remove all spermatozoa. Seminal plasma was pooled from the two stallions and frozen in aliquots at $-20^{\circ} \mathrm{C}$ until used.

\section{Fractionation of seminal plasma}

The protein concentration of pooled seminal plasma was determined using a Bio-Rad-DC protein assay kit ॥ (Bio-Rad, Hercules) as previously described by Bradford (1976). In order to determine the molecular weight range of proteins in equine seminal plasma, proteins were separated by one-dimensional sodium dodecyl sulphate-polyacrylamide gel electrophoresis (SDS-PAGE) in a modified Laemmli buffer system (Laemmli, 1970). Slab gels with total acrylamide-bis concentrations of $15 \%$ or $10 \%$ were used, depending on the molecular weight of the proteins being observed. All gels were run at 150 volts for 1.5 hour with 60 ug protein per lane. Proteins were visualized using Coomassie brilliant blue R-250 $10.1 \%$ in 50\% methanol, $10 \%$ acetic acid).

Seminal plasma proteins were fractionated according to molecular weight by the use of Centricon concentrators (Amicon Inc.) for three different molecular weight cut-offs $(10,000,50,000$ and 100,000 MW). This technique would not affect the biological functionality of the filtered molecules. Aliquots of $2 \mathrm{ml}$ of pooled seminal plasma were placed into Centricon-100, Centroicon-50, and Centricon10 tubes and centrifuged at $3000 \times \mathrm{g}$ for 33 minutes (Centricon-100), at $8,000 \times g$ for 8 minutes (Centricon-50) and at 5,000 x $\mathrm{g}$ for 30 minutes (Centricon-10). More than $90 \%$ of the fluid volume was filtered with the molecules. Therefore, the fractions could be used for function tests without being resuspended.

\section{PMNs}

A total of $20 \mathrm{ml}$ of venous blood was withdrawn from the jugular vein of a clinical healthy gelding in a vacutainer system (Becton Dickinson, Rutherford, NJ) containing sodium-heparin as an anticoagulant. Following centrifugation of the blood at $1,000 \times \mathrm{g}$ for 10 minutes, the plasma was removed and the buffy coat was mixed with an isotonic saline solution $(9 \mathrm{~g} \mathrm{NaCl} / \mathrm{ml})$, layered on lymphocyte separation medium (Organon Teknika, Durham, NC), and centrifuged at $1,000 \times \mathrm{g}$ for 20 minutes. The PMN-rich buffy coat was collected from the pellet underneath the lymphocyte preparation medium and resuspended in a $2.25 \%$ dextran solution (average $M_{r}$ 250,000; Sigma, St. Louis, MO) in saline. After 15 minutes of sedimentation, the supernatant was collected and the cells washed twice with saline and counted.

\section{Standard pooled plasma}

Peripheral venous blood was withdrawn from the jugular vein of 6 clinically healthy adult horses in a vacutainer system (Becton Dickinson, Rutherford, $\mathrm{NJ}$ ) containing sodium-heparin as an anticoagulant. The blood was centrifuged at $1,000 \times \mathrm{g}$ for 10 minutes, and the plasma from all horses removed, pooled, and aliquoted into $2 \mathrm{ml}$ units. These were stored at $-20 \mathrm{C}$ until used.

\section{Chemotactic assay}

In the first experiment $(n=5)$, the concentration of non-fractionated seminal plasma that resulted in an optimal suppression of PMN-chemotaxis was determined. A positive control for PMN-chemotaxis was prepared by mixing 40 ug Escherichia coli lipopolysaccharide (LPS; Sigma, St. Louis, $\mathrm{MO})$ dissolved in $20 \mathrm{ul}$ saline $(9 \mathrm{~g} \mathrm{NaCl} / \mathrm{ml})$, with $400 \mathrm{ul}$ pooled blood plasma. (LPS activates complement in blood plasma through the alternate complement pathway). A negative control for complement induced PMN-chemotaxis was prepared by mixing 40 ug Escherichia coli lipopolysaccharide (LPS; Sigma, St. Louis, MO) dissolved in $20 \mathrm{ul} \mathrm{sa-}$ line $(9 \mathrm{~g} \mathrm{NaCl} / \mathrm{ml})$, with $400 \mathrm{ul}$ heat inactivated blood plasma at $56^{\circ} \mathrm{C}$ for 35 minutes. An additional four test samples of 20 ul LPS were mixed with 400 ul pooled blood plasma in the presence of $10 \mathrm{ul}(\sim 2 \%), 50 \mathrm{ul}(\sim 10 \%), 100 \mathrm{ul}$ $(\sim 20 \%)$, and 200 ul $(\sim 30 \%)$ seminal plasma. Following incubation at $37^{\circ} \mathrm{C}$ for 30 minutes, the samples were heat inac- 
tivated at $56^{\circ} \mathrm{C}$ for 35 minutes and diluted with $1.6 \mathrm{ml} \mathrm{Mc}$ Coy's Medium (Gibco). A total of $0.2 \mathrm{ml}$ of each of the incubated test samples and controls $(0.2 \mathrm{ml}$ of pooled seminal plasma, and $0.2 \mathrm{ml}$ of McCoy's medium alone) was placed in the lower well of a blind-well chemotactic chamber (Neuroprobe Corp., Bethesda, MD). A 2-um pore-size polycarbonate filter (Nucleopore Corp. Pleasanton, CA) was secured in place in the well by a tube-shaped cap into which $0.2 \times 10^{6} \mathrm{PMN}$ in McCoy's medium was added. One hour incubation period in a humified incubator at $37^{\circ} \mathrm{C}$ with $5 \%$ $\mathrm{CO}_{2}$ allowed an optimal number of PMNs to migrate through the filters towards the chemoattractant (unpublished data). After incubation, the remaining cell suspension was removed from the upper compartment of the chamber, and the filters were placed upside-down on a microscopic slide and secured by clips. The PMNs were fixed in $80 \%$ ethanol and stained with hematoxylin (Harleco, EM Diagnostic Systems, Inc., Gibbstown, NJ) and Wright's stain (Camco Quick Stain, Cambridge Chemical Products, Inc., Ft. Lauderdale, FL). The PMNs of eight consecutive microscopic fields were counted at $1000 \times$ magnification in two different areas of the filter, and the mean number of PMNs per field was calculated for each filter. The chemotactic response was expressed as percentage of the positive control. Triplicate assays were performed for each sample, and their means and standard errors of the mean were calculated.

In the second experiment $(n=5)$, each seminal plasma fraction was tested for a suppressive effect on PMN-chemotaxis. Based on the results from the dose dependent

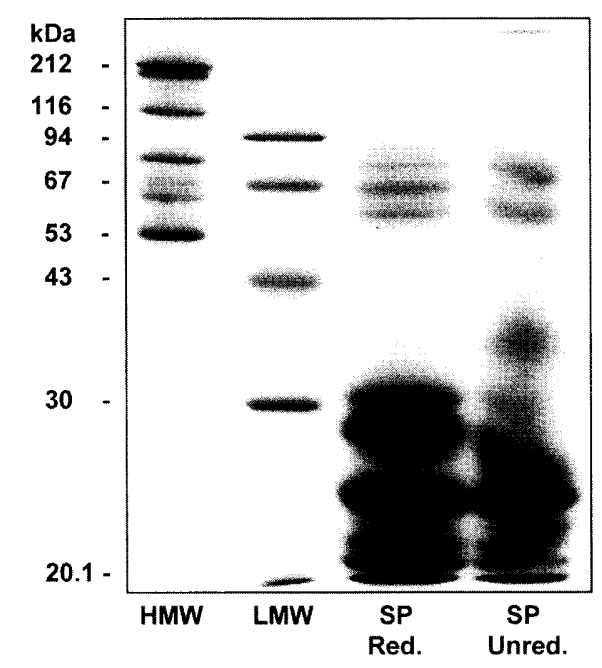

Fig. 1: One-dimensional sodium dodecyl sulphate-polyacrylamide gel electrophoresis (SDS-PAGE) of reduced and unreduced pooled stallion seminal plasma. $\mathrm{HMW}=$ high molecular weight standard; LMW = low molecular weight standard; SP Red. = reduced seminal plasma; SP Unred. $=$ unreduced seminal plasma.

Eindimensionale Natriumdodecyl-SulphatPolyacrylamidGelelektrophorese (SDS-PAGE) von gepooltem Hengstseminalplasma unter reduzierten und nicht reduzierten Bedingungen. $\mathrm{HMW}=$ hochmolekulare Standardproteine, $L M W=$ niedrigmolekulare Standardproteine, SP Red. = Seminalplasma unter reduzierten Bedingungen, $\mathrm{SP}$ Unred. = Seminalplasma unter nicht reduzierten $\mathrm{Be}-$ dingungen. suppression of seminal plasma on PMN-chemotaxis, a total of $50 \mathrm{ul}(10 \%)$ of seminal plasma and each „seminal plasma fraction" was added to 40 ug Escherichia coli lipopolysaccharide (LPS; Sigma, St. Louis, MO) dissolved in 20 ul saline $(9 \mathrm{~g} \mathrm{NaCl} / \mathrm{ml})$, and $400 \mathrm{ul}$ pooled blood plasma. The assay for PMN-chemotaxis was similar to the above described assay. LPS activated blood plasma, heat inactivated blood plasma, and McCoy's media were used as controls.

\section{Statistical analysis}

The effect of different concentrations of seminal plasma, and seminal plasma fractions on chemotaxis was analysed using the Statistical Analysis System, general model. A Duncan's multiple range test was used to determine if the means for the treatment groups differed. The level of significance was set at $p<0.05$.

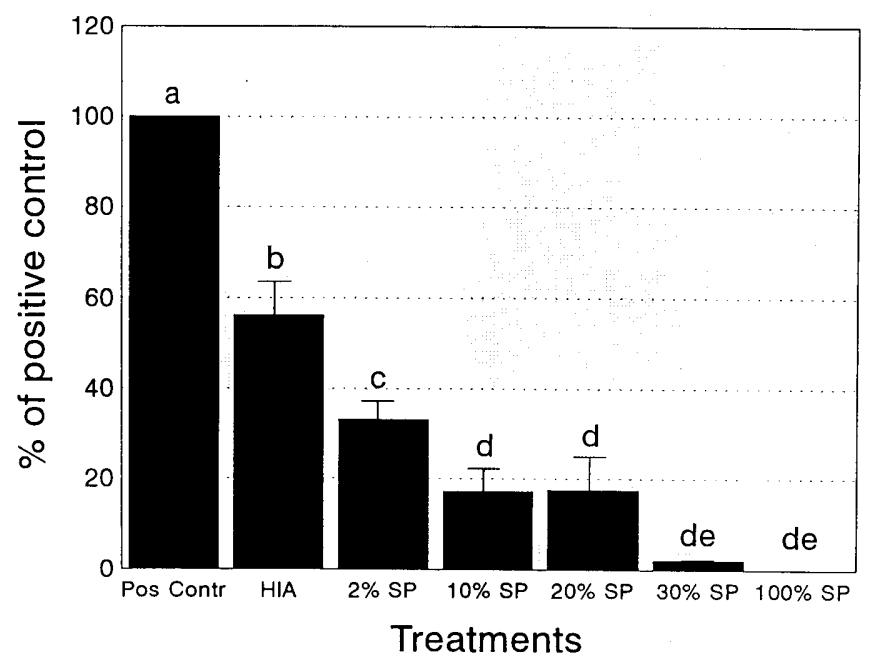

Fig. 2: PMN-chemotaxis in response to LPS-activated blood plasma incubated with increasing concentrations of equine seminal plasma. Data is expressed as percentage (mean \pm SEM) of a standardized chemoattractant (positive control). Different letters a, b, c, d, e indicate significant differences among treatments $(P<0.05)$.

Pos Contr = positive control; HIA = LPS treated heat inactivated blood plasma; $2 \% \mathrm{SP}=2 \%$ seminal plasma; $10 \% \mathrm{SP}=10 \%$ seminal plasma; $20 \% \mathrm{SP}=20 \%$ seminal plasma; $30 \% \mathrm{SP}=30 \%$ seminal plasma; $100 \% \mathrm{SP}=$ $100 \%$ seminal plasma.

PMN Chemotaxis in Abhängigkeit von LPS aktiviertem Blutplasma bei zunehmender Konzentration des Seminalplasmas.

Angabe der Werte als Prozentsatz (Mittelwert mit Standardabweichung) des standardisierten Chemotraktants (Positivkontrolle). a, b, c, d, e bezeichnen verschiedene Behandlungsverfahren $(p<0,05)$. Pos Contr $=$ Positivkontrolle; HIA = LPS behandeltes hitzeinaktiviertes Blutplasma; SP = Seminalplasma

\section{Results}

The majority of proteins in equine seminal plasma was found to have a molecular weight of $<100 \mathrm{kDa}$ (Fig. 1). 
Based on these results, test samples for the chemotaxis experiments were fractionated for molecular weight cut-offs of $<10 \mathrm{kDa},<50 \mathrm{kDa}$ and $<100 \mathrm{kDa}$.

Seminal plasma caused a dose dependent suppression of PMN-chemotaxis $(P<0.001$; Fig 2). A suppression of chemotaxis was observed at all concentrations that were tested. However, concentrations of $10 \%, 20 \%$, and $30 \%$ seminal plasma resulted in greater suppression of PMN-chemotaxis compared to $2 \%$ seminal plasma $(P<0.05)$. Heat inactivation of blood plasma reduced $\mathrm{PMN}$-chemotaxis significantly $(P<0.05)$, but to a lesser extent than seminal plasma $(P<0.05$; Fig. 2).

All seminal plasma fractions reduced $P M N$-chemotaxis $(\mathrm{P}<0.05$; Fig. 3). The greatest suppression of PMN-chemo-

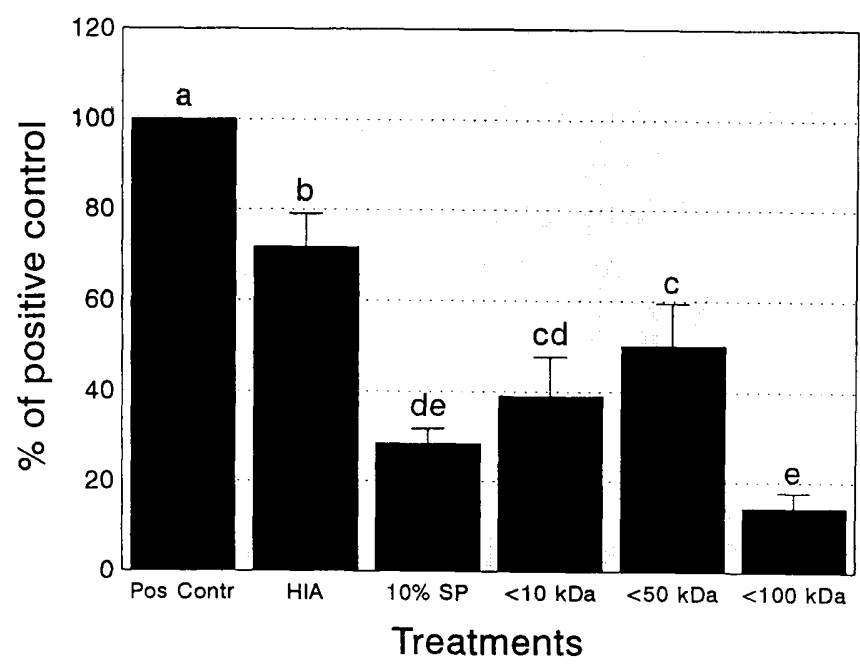

Fig. 3: Suppression of PMN-chemotaxis by three different molecular weight fractions of equine seminal plasma. Data is expressed as percentage (mean \pm SEM) of a standardized chemoattractant (positive control). Different letters $a, b, c, d, e$ indicate significant differences among treatments $(P<0.05)$. Pos Contr $=$ positive control; HIA $=$ LPS treated heat inactivated blood plasma; $10 \% \mathrm{SP}=10 \%$ unfractionated seminal plasma; $<10 \mathrm{kDa}=10 \%$ seminal plasma fraction of molecular weight less than $10 \mathrm{kDa}$; $<50 \mathrm{kDa}=10 \%$ seminal plasma fraction of molecular weight less than $50 \mathrm{kDa} ;<100 \mathrm{kDa}=10 \%$ seminal plasma fraction of molecular weight less than $100 \mathrm{kDa}$.

Suppression der PMN Chemotaxis durch Fraktionen equinen Seminalplasmas mit drei verschiedenen Molekulargewichten.

Angabe der Werte als Prozentsatz (Mittelwert mit Standardabweichung) des standardisierten Chemotraktants (Positivkontrolle). a, b, c, d, e bezeichnen verschiedene Behandlungsverfahren $(p<0,05)$. Pos Contr $=$ Positivkontrolle; HIA = LPS behandeltes hitzeinaktiviertes Blutplasma; $10 \% \mathrm{SP}=10 \%$ unfraktioniertes Seminalplasma; $<10 \mathrm{kDA}=10 \%$ Seminalplasmafraktion mit einem Molekulargewicht unter $10 \mathrm{kDa} ;<50 \mathrm{kDa}=10 \%$ Seminalplasmafraktion mit einem Molekulargewicht unter $50 \mathrm{kDa}$; $<100 \mathrm{kDa}=10 \%$ Seminalplasmafraktion mit einem Molekulargewichrt unter $1000 \mathrm{kDa}$.

taxis was found in the $<100 \mathrm{kDa}$ fraction. The suppressive effect of this fraction was significantly different from the $<10 \mathrm{kDa}$ and $<50 \mathrm{kDa}$ fractions $(P<0.05)$, suggesting that a molecule $>50<100 \mathrm{kDa}$ was responsible for the observed suppression of chemotaxis in the $<100 \mathrm{kDa}$ fraction. All seminal plasma fractions caused a greater suppression of PMN-chemotaxis compared to heat inactivation of blood plasma $(P<0.05)$.

\section{Discussion}

Results from this study demonstrate a dose dependent suppression of PMN-chemotaxis by equine seminal plasma. These findings are in agreement with previous observations (Troedsson et al., 1999; Troedsson et al., 1995). Bull and human seminal plasma has also been shown to suppress complement activation and PMN-chemotaxis (Clark and Klebanoff, 1976; Alexander and Anderson, 1987; Thaler, 1989). Similar to our results, Clark and Klebanoff (1976) isolated a 50-100 KDa fraction in bull seminal plasma that suppressed PMN-chemotaxis. However, to our knowledge this is the first study to characterize the suppressive role of different molecular weight fractions of equine seminal plasma. The functional importance of a suppressive role of seminal plasma on PMN-chemotaxis is not known, but it may serve to modulate the semen induced post-breeding inflammation. Spermatozoa appear to trigger PMN migration into the uterine lumen of mares and sows through activation of PMN-chemotactic factors in blood plasma (Kotilainen et al., 1994; Troedsson et al., 1995a; Rozeboom et al., 1999a). In the sow, seminal plasma appears to protect spermatozoa that are exposed to an inflammatory uterine environment (Rozeboom et al., 1999b). A delay or suppression of a PMN-influx into the uterine lumen may therefore, temporarily protect spermatozoa from being phagocytized. Furthermore, these investigators demonstrated that insemination of porcine spermatozoa in the presence of seminal plasma resulted in a more rapid clearance of PMNs from the uterus compared to insemination of spermatozoa in an extender in the absence of seminal plasma (Rozeboom et al. 1999a). Bedford (1965) suggested that spermatozoa are selectively phagocytized by PMNs in the uterus, and when equine spermatozoa were incubated with PMNs in the presence of uterine secretion in vitro, most sperm cells attached rapidly to the PMNs while some spermatozoa appeared to resist binding to the PMNs (Troedsson et al., 1998b).

Although the greatest suppression of PMN-chemotaxis was found with the 50-100 KDa fraction of seminal plasma, seminal plasma fractions $<50 \mathrm{kDa}$ and $<10 \mathrm{kDa}$ also suppressed PMN-chemotaxis. These results suggest that more than one seminal plasma component is responsible for the modulation of post-breeding inflammation in the mare. However, SDS-PAGE of the fractionated seminal plasma demonstrated that the separation of molecules with different molecular weight was not perfect under the conditions of this study (data not shown). The incomplete separation of molecules may provide an alternative explanation for the suppressive effect of seminal plasma fractions $<10 \mathrm{kDa}$ and $<50 \mathrm{kDa}$. 
More than one mechanism appears to be involved in the suppression of PMN-chemotaxis. We have previously reported that seminal plasma inhibits complement activation, and that seminal plasma suppresses PMN-chemotaxis via inactivation of complement (Troedsson et al., 1998a). However, when compared to PMN-chemotaxis of heat-inactivated blood plasma, a further suppression of PMN-chemotaxis by seminal plasma fractions was still evident. Although part of the suppression may be explained by seminal plasma induced complement inactivation, these findings indicate that mechanisms other than complement inactivation are involved in the effect of seminal plasma on PMN-chemotaxis. Further research is needed to determine the mechanisms of seminal plasma induced suppression on PMNchemotaxis.

In conclusion, this study demonstrated a dose dependent suppression of PMN-chemotaxis by seminal plasma. Both complement dependent and complement independent mechanisms may be involved in this suppression, and although the seminal plasma fraction $>50<100 \mathrm{kDa}$ was the most potent suppressor, other components of seminal plasma may also suppress PMN-chemotaxis.

\section{Literature}

Alexander, N.J. and Anderson, D.J. (1987): Immunology of semen. Fert. Steril. 47, 192-205

Bedford, J.M. (1965): Effect of environment on phagocytosis of rabbit spermatozoa. J. Reprod. Fert. 9, 249-256

Betteridge, K.J., Eaglesome, M.D., Mitchell, D., Flood, P.F., and Beriault, R. (1982): Development of horse embryos up to twentytwo days after ovulation: Observations on fresh specimens. J. Anat., 135, 191-209

Bradford, M. (1976): A rapid and sensitive method for the quantitation of microgram quantities of protein, utilizing the principle of proteindye binding. Anal. Biochem. 72, 248-254

Clark, R.A., and Klebanoff, S.J. (1976): Generation of a neutrophi chemotactic agent by spermatozoa: Role of complement and regulation by seminal plasma factors. J. Immunol. 117, 1378-1386

Freeman, D.A., Woods, G.L., Vanderwall, D.K., and Weber, J.A. (1992): Embryo initiated oviductal transport in the mare. J. Reprod. Fert. 95, 535-538

Kotilainen, T., Huhtinen, M. and Katila, T. (1994): Sperm induced leukocytosis in the equine uterus. Theriogenology 41, 629-636

Laemmli, U.K. (1970): Cleavage of structural proteins during the assembly of the head of bacteriophage T4. Nature 227, 680-685
Rozeboom, K.J., Troedsson, M.H.T., Molitor, T.W., and Crabo, B.G. (1999a): The effect of spermatozoa and seminal plasma on leukocyte migration into the uterus of gilts. J. An. Sci 77: In press)

Rozeboom, K.J., Troedsson, M.H.T., Hodson, H.H., Shurson, G.C., and Crabo, B.G. (1999b): The importance of seminal plasma on spermatozoa viability of subsequent artificial inseminations in swine. J. An. Sci. (In press)

Thaler, C.J. (1989): Immunological role for seminal plasma in insemination and pregnancy. Am. J. Reprod. Fert. 21, 147-150

Troedsson, M.H.T. (1995): Uterine response to semen deposition in the mare. Proc. Society for Theriogenology 130-135

Troedsson, M.H.T., Steiger, B.N., Ibrahim, N.M., Foster, D.N. and Crabo, B.G. (1995a): Mechanism of sperm-induced endometritis in the mare. Biol. Reprod. (Suppl) 52, 307

Troedsson, M.H.T., Crabo, B.G., Ibrahim, N.M., Scott, M., and Ing, M. (1995b): Mating-induced endometritis: Mechanisms, clinical importance, and consequences. Proc. Am. Assoc. Eq. Pract. 41, $11-12$

Troedsson, M.H.T., Lee, C-S., Franklin, R., and Crabo, B.G. (1998a): Post-breeding uterine inflammation: The role of seminal plasma. Proc. VII Int. Symp. Eq. Reprod. 91-92.

Troedsson, M.H.T., Alghamdi, A., Laschkewitsch, T., and Xue, J-L. (1998b): Sperm motility is altered in uterine secretions from mares with post-breeding endometritis. Proc. Am. Assoc. Eq. Pract. 44, 66-67.

\section{Acknowledgements}

This project was supported by the Minnesota Equine Research Center with funds provided by the Minnesota Agricultural Experimental Station and contributions by private donors.

\section{M.H.T. Troedsson}

Department of Clinical and Population Sciences College of Veterinary Medicine

University of Minnesota

St. Paul, MN 55108

\section{R.K. Franklin}

B.G. Crabo

Department of Clinical and Population Sciences and Animal Sciences

University of Minnesota

St. Paul, MN 55108 